reviews the recommendations of the Lacy Commission, annotates them briefly to express the interests of academic libraries, and provides suggestions for revisions in the text where appropriate.

\section{Model Statement}

The Board approved the ACRL "Model Statement of Criteria and Procedures for Appointment, Promotion in Academic Rank, and Tenure for College and University Librarians," as revised by the ACRL Standards and Accreditation Committee, and that the previous version be rescinded. The revised Model Statement will appear in a future issue of $C \mho R L N e w s$.

\section{National conference}

The Board approved the selection of Phoenix, Arizona, as the site for the April 1-4, 1992, ACRL National Conference.

\section{Output measures}

The Board authorized the ACRL Executive Director to contract with a specialist at a cost of no more than \$5,000 to work with the Ad Hoc Committee on Performance Measures to define clearly as many as twelve performance measures for academic libraries that could be developed into a writ-

\section{Recruitment open for editor of ACRL Publications in Librarianship}

ACRL's monographic series, ACRL Publications in Librarianship, will require a new editor to serve on a volunteer basis when Arthur Young completes his term of service. The incoming editor will serve as associate editor from September 1987 to June 1988 and will assume full editorship for a 5-year period in July 1988.

Besides ACRL membership, candidates should have a background of service in academic or research librarianship; experience in research, editing, and bibliographical activities; a concern with publication as a means of professional communication; and an ability to analyze manuscripts for content, research methods, form, structure, or style.

Together with the four- to six-member editorial board, the editor is charged with encouraging research and writing that may be appropriate for the monographic series, soliciting topics and suggesting them to appropriate authors, and editing and refereeing manuscripts.

Persons wishing to be considered for the fiveyear term as editor should communicate their interest, accompanied by a statement of qualifications and names of references, by May 1 , 1987, to: Charles B. Lowry, Director of Libraries, P.O. Box 19497, University of Texas, Arlington, TX 76019. ten manual. The specific measures might be used as the basis for an RFP to potential authors. The Board also requested that the Ad Hoc Committee report to the Board at Annual Conference in San Francisco, and that the issuing of a contract be dependent upon a review by the Budget and Finance Committee and the Board.

\section{Paper reduction}

The Board passed a proposal that the Executive Director look into the feasibility of reducing certain mailings to section chairs and report to the Board at Annual Conference in San Francisco.

\section{Professional ethics}

The Board approved the "Standards for Ethical Conduct for Rare Book, Manuscript, and Special Collections Libraries," developed by a Committee of the Rare Books and Manuscripts Section. These standards are published in this issue on pp.134-35.

\section{Professional Association Liaison Committee}

The Board accepted the recommendation of the Planning Committee that the following task be added to the Professional Liaison Association Committee charge: to coordinate the work of ACRL representatives to other organizations.

\section{Section newsletter policy}

The Board approved a revised version of the ACRL Policy on Section Newsletters and directed ACRL staff to send the revised policy to the sections for comment. The Board will review the comments on the policy at Annual Conference in San Francisco. The revised policy appears on pp.138-39 of this issue.

\section{Washington State University computing services project}

The Board voted to send a letter confirming the importance of a study being conducted at WSU on the organization and integration of library and computing services in the research university.

\section{Women's Studies Section}

The Board approved the Bylaws of the Women's Studies Section, which appear on pp.137-38 of this issue.

\section{This publication is available in microform from University Microfilms International.}

Call toll-free 800-521-3044. Or mail inquiry to: University Microfilms International, 300 North Zeeb Road, Ann Arbor, MI 48106. 